\title{
PERSPEKTYWY ROZWOJU INTEGRACJI KARAIBSKIEJ W RAMACH ZMODYFIKOWANEGO TRAKTATU Z CHAGUARAMAS
}

\section{WPROWADZENIE}

1 stycznia 2006 r. wszedł w życie Zmodyfikowany Traktat z Chaguaramas (Revised Treaty of Chaguaramas - RTC), który przekształcił CARICOM Wspólny Rynek (CARICOM Single Market) ${ }^{1}$ we Wspólny Rynek i Gospodarkę CARICOM (CARICOM Single Market and Economy - CSME) ${ }^{2}$. Jak podkreślił prof. Pollard, modyfikacja Traktatu z Chaguaramas była niezbędna, ponieważ, był on „niczym więcej, niż optyczną iluzja, jeżeli chodzi o egzekwowanie praw i istnienie legalnie wiążących obowiązków”3, co sprawiło, że nie mógł on

${ }^{1}$ Oryginalny Traktat z Chaguaramas, który został podpisany 4 lipca 1973 r. na konferencji szefów rządów państw karaibskich należących do Karaibskiego Stowarzyszenia Wolnego Handlu (CARIFTA), wszedł w życie 1 sierpnia 1973 r. Członkami CARIFTA były: Antigua i Barbuda, Barbados, Belize, Dominika, Grenada, Gujana, Jamajka, Monserrat, St. Kitts/Nevis/Anguilla, St. Lucia, St. Vincent i Grenadyny oraz Trynidad i Tobago (na temat CARIFTA zob. np. R. H. Kempe, CARIFTA and Caribbean Trade: An Overview, „Journal of Caribbean Studies” 1974, nr 14(1), s. 169 i n.

Traktat z Chaguaramas składał się z dwóch części: a więc z właściwego traktatu, który ustanawiał Wspólnotę Karaibska, oraz aneksu, który ustanawiał Wspólny Rynek. Państwa członkowskie CARIFTA mogły przystapić do obu jego części albo tylko do właściwego traktatu. Traktat z Chaguaramas został ratyfikowany przez wyżej wymienione państwa, do których dołączyły Surinam i Haiti. Wyspy Bahama zdecydowały się przystapić do Wspólnoty, ale nie do Wspólnego Rynku. Ten podwójny traktat pozwalał państwu członkowskiemu, które nie życzyło sobie uczestniczyć w systemie Wspólnego Rynku, przystapić tylko do Wspólnoty Karaibskiej. Dodatkowo pozwalał on na zachowanie formalnej więzi pomiędzy państwami członkowskimi Wspólnoty i państwami członkowskimi Wspólnoty i Wspólnego Rynku. Na ten temat zob. H. J Geiser, P. Alleyne, C. Gajraj, Legal Problems of Caribbean Integration: A Study of Legal Aspects of CARICOM, Sijthoff, Leyden 1976, s. 33-34 i 103-104.

${ }^{2} \mathrm{Na}$ temat historii integracji karaibskiej zob. np. bardzo interesujące rozważania D. Berry'ego w monografii: Caribbean Integration Law, OUP, Oxford 2014, s. 17-35. W sposób bardziej szczegółowy historię tę prezentuje Ch. Müllerleile, CARICOM Integration: Progress and Hurdles A European View, 1996, Kingston Publishers, Kingston 1996; zob. też CARICOM Secretariat, CARICOM Our Caribbean Community. An Introduction, CARICOM Secretariat, Kingston, Jamajka 2005.

${ }^{3}$ D. Pollard, Governance Structure of the Caribbean Community, referat wygłoszony na inauguracyjnym seminarium Karaibskiej Akademii Prawa i Administracji Wymiaru Sprawiedliwości (The Caribbean Academy for Law and Court Administration), które odbywało się w Port of Spain na Trynidadzie od 6 do 10 grudnia 2010 r. 
sprostać wymogom globalizacji i zapewnić zrównoważonego rozwoju regionu karaibskiego $0^{4}$.

Traktat RTC ratyfikowało 13 następujących państw karaibskich: Antigua i Barbuda, Barbados, Belize, Dominika, Grenada, Gujana, Haiti, Jamajka, St. Kitts/Nevis, St. Lucia, St. Vincent i Grenadyny, Trynidad i Tobago oraz Surinam. Natomiast Bahamy i Montserrat, zgodnie ze specjalnymi porozumieniami podpisanymi z CARICOM, sa tylko członkami Wspólnoty Karaibskiej ${ }^{5}$. Wszystkie państwa członkowskie, z wyjątkiem Haiti, są także stronami Porozumienia ustanawiającego Karaibski Trybunał Sprawiedliwości (Caribbean Court of Justice - CCJ) ${ }^{6}$.

Karaibski Trybunał Sprawiedliwości powstał w kwietniu 2005 r. i ma swoją siedzibę w Port of Spain. Jego jurysdykcja ma podwójny charakter. Z jednej strony jest on najwyższym sądem apelacyjnym, zastapił bowiem Brytyjski Sadowy Komitet Rady Prywatnej (ang. Judicial Committee of the Privy Council - JCPC), który od ponad 300 lat jest najwyższym sądem apelacyjnym dla region karaibskiego ${ }^{7}$. Dotychczas tylko 3 państwa CARICOM zrezygnowały z jurysdykcji JCPC i zaakceptowały CCJ jako swój najwyższy sąd apelacyjny (Barbados, Belize i Gujana). Z drugiej strony realizuje własną tzw. oryginalna jurysdykcję, która jest obligatoryjna i ekskluzywna. Rozciaga się ona na sprawy dotyczace wykładni i stosowania RTC oraz występuje w zakresie rozstrzygania sporów wynikających z $\mathrm{RTC}^{8}$. Kompetencje ratione iuris Trybunału w ramach tej jurysdykcji określają postanowienia art. 217(1) RTC. W procesie orzekania $\mathrm{w}$ ramach oryginalnej jurysdykcji Trybunał stosuje odpowiednie normy prawa międzynarodowego.

Artykuł 6 RTC wymienia następujące zasadnicze cele CSME:

a) poprawa warunków życia i pracy;

b) pełne zatrudnienie oraz wykorzystanie innych czynników produkcji;

c) przyśpieszony, skoordynowany i zrównoważony wzrost gospodarczy;

d) rozwój stosunków gospodarczych i handlowych z krajami trzecimi;

e) wzmocnienie konkurencyjności międzynarodowej;

f) zapewnienie wzrostu produkcji i produktywności;

${ }^{4} \mathrm{Na}$ ten temat zob. C. Dundas, Essays on the Law and Practice of the Caribbean Community, Including the Common Market, „West Indian Law Journal” 1979, s. 19-31; zob. też Grand Anse Declaration i Work Programme for the Advancement of the Integration Movement, Grand Anse, Grenada, 7 July1989 (http://www.caricom.org/jsp/communications/meetings_statements/grand_ anse_declaration.jsp?menu=communications [dostęp: 10.04.2014]); CARICOM Secretariat, 'Communiqué Issued at the Conclusion of the Tenth Meeting of the Conference of Heads of Government of the Caribbean Community, 3-7 July 1989, Grand Anse, Grenada (http://www.caricom.org/jsp/ communications/communiques/10hgc_1989_communique.jsp [dostęp: 10.04.2014]).

${ }^{5}$ Stan z września 2013; zob. D. Berry, op. cit., s. 53.

${ }^{6}$ Tekst Porozumienia można znaleźć na: http://www.caricom.org/jsp/secretariat/legal_instruments/agreement_ccj.pdf (dostęp: 16.04.2014).

7 The JCPC jest najwyższym sądem apelacyjnym dla zamorskich terytoriów UK, terytoriów zależnych i dla tych państw Wspólnoty Brytyjskiej, które po uzyskaniu niepodległości zadecydowały się zachować JCPC jako swój najwyższy sąd.

${ }^{8}$ Szerzej zob. D. Berry, op. cit., s. 395-3966; H. M. Salmon, The Caribbean Court of Justice: A March with Destiny, „Florida Coastal Law Journal” 2, 2000, s. 234. 
g) osiagnięcie większej siły ekonomicznej i efektywności w stosunkach z krajami trzecimi;

h) wzmocniona koordynacja polityki zagranicznej i polityki zagranicznej dotyczącej spraw ekonomicznych;

i) wzmocniona współpraca funkcjonalna zwłaszcza poprzez:

(i) większą efektywność w sferze usług publicznych i działalności przynoszącej korzyści społeczeństwu państw członkowskich;

(ii) intensyfikację procesu promocji większego zrozumienia pomiędzy społeczeństwami państw członkowskich i ich rozwoju społecznego, kulturalnego oraz technologicznego;

(iii) intensywne działania w sektorze zdrowia, edukacji, telekomunikacji i transportu.

Podstawą Wspólnego Rynku i Gospodarki CARICOM są: swoboda przepływu towarów, swoboda przepływu osób (ograniczona do osób o najwyższych kwalifikacjach i artystów), swoboda przepływu usług, swoboda przepływu kapitału, prawo do prowadzenia działalności gospodarczej w dowolnym państwie członkowskim, wspólna taryfa celna oraz wspólna polityka handlowa. Proces integracji jest wspierany przez harmonizację ustawodawstwa dotyczącego prawa bankowego i ubezpieczeniowego, prawa spółek, prawa własności intelektualnej i przemysłowej, prawa konkurencji i ochrony konsumentów, koordynacji polityki walutowej, stóp procentowych, podatków pośrednich oraz działań zmierzających do ograniczenia deficytu finansów publicznych.

Niestety od swojego wejścia w życie do dnia dzisiejszego RTC przyczynił się w bardzo małym stopniu do pogłębienia procesu integracji karaibskiej. W opublikowanym w roku 2011 raporcie Instytutu Stosunków Międzynarodowych Uniwersytetu Indii Zachodnich, zatytułowanym: „Integracja w rejonie karaibskim” czytamy: „[...] interesariusze wyrażają swój głęboki pesymizm co do przyszłości integracji w ramach CARICOM, widząc region karaibski obarczony brakiem wizji, słabą realizacją decyzji organów CARICOM, brakiem zaufania, słabym przewodnictwem i niemoca instytucji Wspólnoty"9.

Zdaniem autorki, należy wskazać na trzy najważniejsze przyczyny braku oczekiwanego postępu w procesie pogłębiania regionalnej integracji karaibskiej

1) przywiązanie państw członkowskich do dualizmu;

2) podejmowanie decyzji przez organy CSME, oparte na metodzie międzyrządowej i

3) brak sankcji w stosunku do państwa członkowskiego, które nie stosuje się do orzeczenia CCJ stwierdzającego naruszenia prawa wspólnotowego.

Niżej zostaną zaprezentowane szczegółowe uwagi na temat wpływu tych czynników na rozwój integracji karaibskiej. Jeżeli chodzi o pierwszy i trzeci czynnik, zostaną one poddane analizie w świetle odpowiednich orzeczeń CCJ. Pozwoli to stwierdzić, w jakim stopniu CCJ przyczynił się do przezwyciężenia trudności wynikających $\mathrm{z}$ istnienia tych czynników w procesie realizacji działań integracyjnych.

9 Tekst raportu zob.: http://www.normangirvan.info/wp-content/uploads/2011/06/iir-regional-integration-report-final.pdf, s. 4 (dostęp: 17.04.2014). 


\section{DUALIZM JAKO PRZESZKODA NA DRODZE OSIĄGNIĘCIA CELÓW ZDEFINIOWANYCH W ART. 6 RTC}

Dla zaprezentowania tej problematyki badawczej należy: po pierwsze dokonać analizy teorii dualizmu i przedstawić jej wpływ na rozwój regionalnej integracji karaibskiej oraz - po drugie - rozważyć, w jakim stopniu orzeczenie CCJ w sprawie Trinidad Cement Limited (TCL), TCL Guyana Incorportaed (TGI) $v$ The State of the Co-operative Republic of Guyana ${ }^{10}$ lagodzi skutki prawne wynikające z art. 240 RTC, w którym państwa członkowskie CARICOM wyraźnie postanowiły, że stosunek pomiędzy prawem wspólnotowym i prawem wewnętrznym ma być oparty na poszanowaniu wymogów teorii dualizmu.

\section{Dualizm i jego wpływ na rozwój integracji regionalnej}

Spośród 15 państw członkowskich CARICOM 12 państw jest określanych jako Caribbean Commonwealth Countries (CCC). Sa to angielskojęzyczne wyspy: Antigua i Barbuda, Bahamy, Barbados, Dominika, Grenada, Jamajka, St. Kitts i Nevis, St. Lucia, St. Vincent i Grenadyny, Trynidad i Tobago oraz dwa państwa kontynentalne: Belize i Gujana. Państwa te w okresie kolonialnym stanowiły karaibska cześć Imperium Brytyjskiego. W momencie uzyskania niepodległości, jako część ich kolonialnego dziedzictwa, przyjęły teorię dualizmu na określenie stosunku pomiędzy prawem międzynarodowym i wewnętrznym ${ }^{11}$. Jednakże, inaczej aniżeli w Zjednoczonym Królestwie Wielkiej Brytanii i Irlandii Północnej, w państwach tych konstytucja, a nie parlament jest uważana za suwerena ${ }^{12}$.

Teoria dualizmu w prawie międzynarodowym zakłada, że prawo międzynarodowe i prawo wewnętrzne stanowia dwa niezależne, oddzielne i odmienne systemy prawne. Konsekwencją dualizmu jest więc to, że norma prawa międzynarodowego nie może być źródłem prawa wewnętrznego. Każda norma prawna jest stosowana i wywołuje skutki prawne w tym systemie, z którego się wywodzi. Z tego powodu niemożliwa jest kolizja prawna pomiędzy normą prawa międzynarodowego i normą prawa wewnętrznego. Prawo wewnętrzne sprzeczne z normą międzynarodową nie traci swojej ważności, chociaż państwo, które łamie normę międzynarodowa, może ponieść za to odpowiedzialność, ale tylko na forum międzynarodowym. Prawo międzynarodowe, żeby być zastosowane wewnątrz państwa, musi zostać przekształcone w prawo wewnętrzne w procedurze transformacyjnej, a więc przez odpowiednią ustawę implementacyjna.

10 [2009] CCJ 1 (OJ).

11 S. Vasciannie, The Relationship between International Law and Caribbean Domestic Law, „West Indian Law Journal” 32, 2007, nr 1, s. 51.

${ }^{12} \mathrm{Na}$ ten temat zob. P. Eleftheriadis, Parliamentary Sovereignty and the Constitution, „Canadian Journal of Law and Jurisprudence” 22, 2009, nr 2, s. 1. Zob. też Independent Jamaica Council for Human Rights Limited v Honourable Syringa Marshall-Burnett and The Attorney-General of Jamaica (2005) UKPC 3. 
W państwach CCC, tak jak w Zjednoczonym Królestwie, normy prawa międzynarodowego zwyczajowego nie wymagają aktu transformacji, a więc sa częścią prawa wewnętrznego na podstawie teorii inkorporacji pod warunkiem, że nie koliduja one z prawem ustanowionym przez parlament ani z autorytatywnymi decyzjami sądowymi ${ }^{13}$.

W stosunku do umów międzynarodowych dualizm wymaga ich transformacji, tzn. wymaga, żeby umowa międzynarodowa zawarta przez rząd była później przedmiotem uchwalenia przez parlament ustawy implementacyjnej, bez której taka umowa nie staje się częścią wewnętrznego porządku prawnego i w konsekwencji nie może być w nim stosowana.

Dualizm stanowi gwarancję, że parlament jest najwyższym ustawodawca i że umowy zawarte przez władzę wykonawczą w sferze międzynarodowej nie mają wpływu na zakres władzy ustawodawczej parlamentu, który może odrzucić, zmodyfikować albo zaakceptować umowę międzynarodową. Dualizm jest też skutecznym sposobem na zachowanie suwerenności parlamentu i zapewnienie, że władza wykonawcza nie ma kompetencji do tego, aby ograniczyć zakres władzy parlamentu w sferze wewnętrznej. To sprawia, że obywatele sa chronieni przed możliwością zmiany wewnętrznego porządku prawnego bez zgody parlamentu.

Po drugiej wojnie światowej w prawie międzynarodowym nastapiły bardzo daleko idące przeobrażenia, jeżeli chodzi o jego podmioty, system źródeł, zakres zastosowania i sposoby egzekwowania. W szczególności powstanie i rozwój organizacji międzynarodowych w dziedzinie regionalnej integracji pokazały, że dualizm stanowi poważną przeszkodę w procesie pogłębienia integracji. Wynikało to zwłaszcza z tej jego szczególnej cechy, która oznaczała, że ustanawiające takie organizacje umowy międzynarodowe, ich modyfikowanie w trakcie realizacji procesów integracyjnych oraz prawo stanowione w ramach takich organizacji wymagały transformacji, aby wywołać określone skutki prawne w prawie wewnętrznym państw członkowskich.

Oceniajac proces transformacji, można powiedzieć, że ma on następujace niepożądane skutki na rozwój regionalnej integracji:

Po pierwsze - parlamenty narodowe moga wnieść poprawki i modyfikacje do tekstu traktatu założycielskiego. Takie poprawki i modyfikacje moga naruszać jednolitość stosowania postanowień traktatu. Ponadto fakt, że regulacje prawne uchwalone przez instytucje i organy regionalnych organizacji integracyjnych moga zostać zmodyfikowane albo odrzucone przez parlamenty

${ }^{13}$ Zob. Lord Denning, w: Trendtex Trading Corporation v Central Bank of Nigeria [1977] QB 529, s. 554; Westland Helicopters Ltd v Arab Organisation for Industrialisation [1995] 2 All ER 387 oraz orzeczenia wydane w sprawie Pinochet (np. Lord Lloyd powiedział, że prawo zwyczajowe „form part of the common law of England”), w: $R v$ Bow Street Metropolitan Stipendiary Magistrate, ex parte Pinochet Ugarte (No 3 [2000] 1 AC 61. Zob. też orzeczenie Izby Lordów w sprawie Sadem v R v Jones [2006] UKHL 16, które wywołało dyskusję na temat tego, czy decyzja Lorda Denninga w Trendex Trading Corporation, która uznała teorię inkorporacji prawa zwyczajowego, jest nadal aktualna. Ponadto zob. J. Crawford, Brownlie's Principles of International Law, wyd. 8, OUP, Oxford 2012, s. 67-71; R. Jennings, A. Watts, Oppenheim's International Law, wyd. 9, Longman, London 1996, s. 56-57; R. Jennings, An International Lawyer Takes Stock, „International Comparative Law Quarterly" 39, 1990, s. 523. 
narodowe w procesie transformacji, sprawia, że najważniejszy cel, dla osiagnięcia którego taka organizacja została powołana do życia, a więc stworzenie jednolitych, wszechstronnych i powszechnych norm prawnych w państwach członkowskich, zostanie w oczywisty sposób zakwestionowany.

Po drugie - proces transformacji jest zwykle czasochłonny, co wynika $\mathrm{z}$ faktu, że parlament podejmuje i realizuje zgodnie z procedurą ustawodawcza obowiąujacca w danym państwie działania niezbędne do uchwalenia ustawy implementacyjnej dla zapewnienia, że akty prawne regionalnej organizacji mają odpowiednią moc prawną na gruncie wewnętrznego porządku prawnego. To powoduje istotne opóźnienia w osiaganiu celów integracji, jak również podważa jednolitość stosowania prawa wspólnotowego.

Po trzecie - kiedy prawo wspólnotowe zostaje przekształcone w prawo wewnętrzne, ma ono taki sam status prawny jak każda ustawa. W rezultacie każda późniejsza ustawa ma pierwszeństwo w stosowaniu przed ustawa, która przekształciła traktat założycielski, albo akty prawne uchwalone przez instytucje i organy regionalnej organizacji, w sytuacji kiedy późniejsza ustawa koliduje z wcześniejsza. To powoduje nie tylko fragmentację prawa wspólnotowego, ale także wprowadza niepewność w jego stosowaniu w sferze wewnętrznej.

\section{Skutki prawne wynikające $\mathrm{z}$ art. $240 \mathrm{RTC}$ i ich wpływ na rozwój} integracji karaibskiej w świetle orzeczenia CCJ w sprawie Trinidad Cement Limited (TCL), TCL Guyana Incorportaed (TGI) $v$ The State of the Co-operative Republic of Guyana ${ }^{14}$

Artykuł 240 RTC stanowi, co następuje: „Decyzje kompetentnych organów uchwalonych zgodnie z tym Traktatem będa przedmiotem konstytucyjnych procedur w państwach członkowskich, zanim uzyskają moc prawna pozwalająca na kreowanie praw i obowiązków dla obywateli tych państw. Państwa członkowskie zobowiąują się zatem do tego, że decyzje ich kompetentnych organów uchwalane zgodnie z traktatem uzyskają szybko moc obowiąujacca w prawie wewnętrznym"15.

Należy więc podkreślić, że państwa członkowskie CARICOM w art. 240 RTC wyraźnie dały do zrozumienia, że ich uczestnictwo w projekcie integracyjnym jest uwarunkowane zachowaniem dualistycznego stosunku pomiędzy prawem wewnętrznym i prawem wspólnotowym, i tym samym uniemożliwiły ustanowienie zasad bezpośredniego stosowania i bezpośredniej skuteczności prawa wspólnotowego przez CCJ.

Oczywiście CCJ może podjąć próbę interpretacji postanowień art. 240 RTC contra legem, ale taka interpretacja byłaby sprzeczna z misją CCJ, który ma

14 [2009] CCJ 1 (OJ).

15 Oryginalna wersja art. 240 RTC: „1. Decisions of competent Organs taken under this Treaty shall be subject to the relevant constitutional procedures of the Member States before creating legally binding rights and obligations for nationals of such States. 2. The Member States undertake to act expeditiously to give effect to decisions of competent Organs and Bodies in their municipal law". 
interpretować i stosować prawo wspólnotowe i konsekwentnie nie ma kompetencji do stanowienia norm tego prawa. Sytuacja ta oznacza poważny dylemat dla Trybunału. Z jednej strony, zgodnie z misja, która została mu powierzona przez państwa członkowskie, ma on za zadanie rozwijać prawo wspólnotowe, ale z drugiej - ten rozwój jest w dużej mierze hamowany przez art. 240 RTC. Pomimo tego CCJ użył środków, które sprawiły, że restrykcje nałożone przez ten przepis zostały w dużym stopniu przezwyciężone.

Trybunał w orzeczeniu w sprawie: Trinidad Cement Limited (TCL), TCL Guyana Incorportaed (TGI) $v$ The State of the Co-operative Republic of Guyana ${ }^{16}$, opierając się na postanowieniach art. 9 RTC, który nakłada na państwa członkowskie obowiązek podjęcia wszelkich środków ogólnych lub szczególnych, właściwych dla zapewnienia wykonania zobowiązań wynikających z RTC lub z aktów prawnych uchwalanych przez instytucje i organy CARICOM i powstrzymania się od podejmowania wszelkich działań, które mogłyby zagrażać osiagnięciu celów CARICOM, stwierdził, że RTC ustanawia nie tylko prawa i obowiązki dla państw członkowskich, ale także skorelowane z nimi prawa dla ich obywateli.

Sprawa TCL dotyczyła TCL - spółki z ograniczoną odpowiedzialnością z siedzibą na Trynidadzie i Tobago i jej filii TGI - spółki z ograniczoną odpowiedzialnością z siedzibą na Trynidadzie i Tobago oraz w Gujanie, które zajmowały się produkcja, pakowaniem, sprzedażą i dystrybucją cementu w państwach członkowskich CARICOM. Obie spółki wniosły skargę przeciwko Gujanie, zarzucając jej naruszenie postanowień art. 82 RTC poprzez zawieszenie stosowania Wspólnej Taryfy Zewnętrznej (Common External Tariff - CET) na cement importowany z państw nienależących do CARICOM. Spółki dowodziły, że zawieszenie CET spowodowało wymierne straty, głównie związane ze spadkiem popytu na ich cement w państwach CARICOM. Gujana przyznała, że zawiesiła CET bez otrzymania upoważnienia od kompetentnego organu CARICOM, a więc Rady do spraw Handlu i Rozwoju Gospodarczego, co oznaczało naruszenie postanowień art. 82 RTC. Na swoją obronę Gujana podniosła argument, że ani TLC, ani TGI nie mogą korzystać z locus standi przed CCJ, ponieważ nie spełniały warunków zdefiniowanych w postanowieniach art. 222 RTC. Przepis ten określa możliwości skierowania przez podmiot prywatny wniosku do CCJ o wszczęcie postępowania przeciwko państwu członkowskiemu z tytułu naruszenia postanowień traktatu. Artykuł 222 RTC przewiduje skomplikowane i kumulatywne warunki, które musi spełnić taki podmiot, aby uzyskać locus standi w sprawie przed CCJ. Pierwsze dwa warunki wymagaja, aby powód dowiódł, że RTC zamierzał prawo lub korzyść przyznaną państwu członkowskiemu przyznać bezpośrednio powodowi i że powód został pokrzywdzony w korzystaniu z nich. Tekstualna wykładnia artykułów RTC dotyczących CET wydaje się uzasadniać przyznanie prawa i nakładanie obowiązków tylko na państwo członkowskie. Jednakże CCJ stwierdził, że chociaż RTC nie zawsze wyraźnie nadaje prawa albo korzyści podmiotom prywatnym, to jednak pozwala na ich ustanowienie na podstawie korelatywnych obowiązków nałożonych na państwa członkowskie. CCJ stwierdził wprost, że:

16 [2009] CCJ 1 (OJ). 
„Jeżeli obowiązek został nałożony na państwo członkowskie (albo kolektywnie na grupę państw członkowskich), może na jego podstawie zostać ustanowione skorelowane prawo, które gwarantuje przyznanie bezpośredniej korzyści podmiotom prywatnym"17.

Należy podkreślić, że powołanie przez CCJ doktryny „skorelowanego prawa" jest ważnym etapem w procesie rozwoju CSME, ponieważ sprawia ona, że RTC jest potencjalnie stosowany w sytuacji, w której konkretny obowiązek jest nałożony na państwo członkowskie. Doktryna ta była bardzo ważna z punktu widzenia interesów obu pozywających spółek: TCL i TGI. Bez istnienia takiego skorelowanego prawa ani TCL, ani TGI nie byłyby bowiem w stanie spełnić dwóch pierwszych warunków ustanowionych przez art. 222 RTC, co w konsekwencji spowodowałoby oddalenie ich wniosku przez CCJ.

Można też sformułować tezę, że doktryna „skorelowanego prawa” pozwala w pewnym stopniu złagodzić negatywne skutki wynikające z dualizmu, ponieważ podmioty prywatne uzyskały łatwiejszy dostęp do CCJ. Mogą one, po spełnieniu warunków określonych w art. 222 RTC, inicjować postępowanie przed CCJ w sytuacji, w której państwo członkowskie nie dokonało jeszcze procesu transformacji. Z drugiej strony brak taki przekreśla możliwość dochodzenia przez podmioty prywatne przed sądem krajowym praw opartych na RTC. Należy jednak podkreślić, że doktryna „skorelowanego prawa” ma ograniczone zastosowanie, a więc może zostać wykorzystana w postępowaniu przed CCJ tylko wtedy, kiedy rozpatruje on sprawę wchodzącą w zakres jego oryginalnej jurysdykcji.

W sprawie TCL i TGI przeciwko Gujanie CCJ wyjaśnił drugą ważną zasadę dotyczaca ustanowienia locus standi na podstawie art. 222 RTC. Gujana twierdziła bowiem, że TGI, jako spółka z siedzibą w Gujanie, nie miała prawa rozpoczęcia postępowania przed CCJ, ponieważ z tekstualnej wykładni art. 222(c) RTC wyraźnie wynika, że podmiot prywatny nie może zaskarżyć państwa, którego jest obywatelem. Artykuł 222(c) RTC wymaga, żeby taki podmiot w celu ustanowienia locus standi dowiodł, że państwo członkowskie, które ma prawo poprzeć jego roszczenie przed CCJ, albo zrezygnuje z tego prawa, albo wyraźnie zgodzi się na to, aby zamiast niego podmiot prawny mógł dochodzić swoich praw. Gujana argumentowała, że art. 222(c) RTC zawsze daje państwu członkowskiemu prawo dochodzenia roszczenia w imieniu poszkodowanego podmiotu prywatnego i tym samym wyklucza sytuację, w której państwo członkowskie może być w tej samej sprawie zarówno powodem, jak i pozwanym. CCJ zgodził się z Gujana, że tekstualna wykładnia art. 222(c) RTC mogłaby prowadzić do takiego rezultatu. Jednakże CCJ przyjął, że art. 222(c) RTC powinien być interpretowany zgodnie z wykładnią teleologiczna. Odrzucając zasadność stosowania wykładni tekstualnej, CCJ oparł się na trzech następujących argumentach.

Po pierwsze - Trybunał stwierdził, że analiza RTC nie potwierdza, że art. 222(c) RTC powinien być przedmiotem wykładni tekstualnej.

${ }^{17}$ Ibidem, par. 32. „Where an obligation is [imposed on Member States (or a class of Member States) collectively], it is capable of yielding a correlative right that enures directly to the benefit of private entities throughout the entire Community". 
Po drugie - CCJ zauważył, że państwa członkowskie nie miały intencji pozbawienia podmiotów prywatnych możliwości wszczynania postępowania przed CCJ przeciwko państwu członkowskiemu, którego jest taki podmiot obywatelem. CCJ wyjaśnił, że trzy argumenty potwierdzają tę konkluzję. Argument pierwszy sprowadzał się do stwierdzenia, że tekstualna wykładnia zagraża urzeczywistnieniu celów RTC, biorąc pod uwagę fakt, że mogłaby ona mieć negatywny wpływ na zakres praw obywateli i innych osób, niebędących obywatelami państw członkowskich. W szczególności obywatele innych państw członkowskich, którzy założyli spółki z siedzibą w państwie członkowskim, któremu stawiany jest zarzut naruszenia prawa wspólnotowego, byliby głęboko pokrzywdzeni, ponieważ nie mieliby możliwości dochodzenia swoich praw przed CCJ. Trybunał podkreślił przy tym, że zastosowanie wykładni tekstualnej mogłoby doprowadzić do sytuacji, w której państwo członkowskie byłoby wręcz zachęcone do łamania prawa wspólnotowego, ponieważ nie ponosiłoby żadnej odpowiedzialności za takie naruszenie w stosunku do podmiotu prywatnego innego państwa członkowskiego. Argument drugi bazował na art. XVIII(1) Umowy ustanawiającej CCJ, który to artykuł pozwala państwu członkowskiemu, organom CARICOM i podmiotom prywatnym wystąpić $\mathrm{z}$ wnioskiem o przyznanie statusu interwenienta $\mathrm{w}$ sprawie znajdujacej się na wokandzie CCJ w sytuacji, kiedy istotny interes natury prawnej wyżej wymienionych może być naruszony przez orzeczenie Trybunału w tej sprawie. Zgodnie z tymi postanowieniami podmiot prywatny może interweniować nie tylko na rzecz państwa członkowskiego, którego jest obywatelem, lecz także przeciwko niemu. Trzeci argument był oparty na postanowieniach art. 7 RTC, który zabrania dyskryminacji ze względu na przynależność państwową. CCJ stwierdził, że tekstualna wykładnia postanowień art. 222(c) RTC doprowadziłaby do naruszenia zakazu dyskryminacji ze względy na przynależność państwowa, ponieważ naruszyłaby zasadę równego dostępu do wymiaru sprawiedliwości, tzn. zasadę równego dostępu do CCJ. Oznaczałoby to, że w przedmiotowej sprawie TCL miałaby dostęp do CCJ, ponieważ spółka miała siedzibę na Trynidadzie i Tobago, ale TGI nie mogłaby dochodzić swoich praw przed CCJ tylko dlatego, że miała swoją siedzibę w Gujanie.

Po trzecie - wreszcie CCJ stwierdził, ze teleologiczna wykładnia gwarantuje, że cel art. 222(c) RTC, polegający na eliminacji „podwójnego” postępowania przeciwko państwu członkowskiemu, któremu zarzuca się naruszenie prawa wspólnotowego, będzie osiagnięty, biorąc pod uwagę fakt, że RTC przyznaje prawo wszczęcia postępowania przeciwko temu państwu zarówno innym państwom członkowskim, jak i podmiotom prywatnym. W konsekwencji teleologiczna wykładnia powoduje, że tylko jedna sprawa oparta na tych samych faktach i przesłankach może być wszczęta przed CCJ, a więc albo przez państwo członkowskie w imieniu poszkodowanego podmiotu prywatnego, albo przez taki podmiot w sytuacji, kiedy państwo członkowskie, którego obywatelem jest ten podmiot, odmówi wniesienia skargi.

Dodać należy, że w sprawie TCL i TGI Trybunał był bardzo wspaniałomyślny, jeżeli chodzi o określenie spoczywającego na stronie powodowej ciężaru dowodu. CCJ stwierdził, że na etapie, w którym podmiot prywatny wnioskuje 
o wszczęcie postępowania przeciwko państwu członkowskiemu, wystarczy, że przedstawi on istnienie dowodu prima facie $\mathrm{w}$ sprawie.

\section{Konkluzje}

W konkluzji tej części rozważań należy podkreślić, że CCJ spotyka się z wyraźnym oporem ze strony państw członkowskich CARICOM, które za wszelką cenę starają się o podtrzymanie przy życiu i stosowanie wskazanego wyżej dualizmu dla zapewnienia, że ani zasada bezpośredniego stosowania, ani zasada bezpośredniej skuteczności nie będą transplantowane z Unii Europejskiej na Karaiby. Trybunał zdołał jednak znaleźć innowacyjne i oryginalne sposoby na pogłębienie integracji w ramach CARICOM. Z drugiej jednak strony należy zauważyć, że teleologiczna wykładnia art. 222 RTC, która zapewnia szeroki dostęp dla podmiotów prywatnych do CCJ, na dłuższą metę może mieć negatywne skutki, a więc może spowodować masowy napływ roszczeń wnoszonych przez podmioty prywatne przeciwko państwom członkowskim, co z kolei może spowodować istotną zwłokę w wydawaniu orzeczeń przez CCJ, a nawet wpłynąć na ich jakość.

\section{ZASADY PODEJMOWANIA DECYZJI PRZEZ ORGANY CARICOM OPARTE NA METODZIE MIĘDZYRZĄDOWEJ}

\section{Uwagi ogólne}

Sposób podejmowania decyzji przez organy CARICOM ma istotne konsekwencje dla procesu rozwoju integracji w ramach tej organizacji. Artykuł 10(1) RTC wymienia następujące organy główne CARICOM:

1) Konferencja Szefów Rządów (CARICOM Heads of Government - CHG) organ z rotacyjnym przewodnictwem, wyznaczający polityczne priorytety współpracy;

2) Rada Ministrów Wspólnoty (Community Council of Minister - CCM) w składzie ministrów, członków rządów krajowych odpowiedzialnych za sprawy wspólnotowe lub innych wyznaczonych ministrów.

Zgodnie z postanowieniami art. 10(2) RTC organy główne są wspomagane przez cztery następujące rady ministrów, jako organy o charakterze doradczym: Radę do spraw Finansów i Planowania (COFAP); Radę do spraw Handlu i Rozwoju Gospodarczego (COTED), Radę do spraw Zagranicznych i Wspólnotowych (COFCOR) i Radę do spraw Rozwoju Społecznego (COHSOD). $\mathrm{W}$ strukturze instytucjonalnej CARICOM znajdujemy ponadto trzy komitety, jako organy o charakterze pomocniczym, a więc: Komitet Budżetowy, Komitet do spraw Prawnych i Komitet Gubernatorów Banków Centralnych. Organem o charakterze administracyjnym jest Sekretariat Generalny, na czele którego stoi sekretarz generalny rekomendowany przez CCM i wybierany przez CHG na okres nieprzekraczajaccy 5 lat. Pełni on funkcje reprezentacyjne i nadzoruje wykonanie programów i działań zmierzających do realizacji celów CARICOM. 
W tak określonej strukturze instytucjonalnej CARICOM najważniejszą rolę odgrywają: CHG i CCM, wspierane przez cztery rady ministrów: COFAB, COTED, COFCOR i COHSOD.

Wybór metody współpracy państw członkowskich dla realizacji statutowych zadań i osiagania statutowych celów jest w przypadku każdej organizacji międzynarodowej o charakterze integracyjnym jednym z głównych czynników decydujacych o rozwoju lub zastoju regionalnej integracji. CARICOM wybrał wyłącznie metodę międzyrządowa, której realizacja jest oparta na zachowaniu suwerenności państw członkowskich. Neill Nugent scharakteryzował tę metodę jako: „Układy, za pomocą których państwa w sytuacjach i warunkach, które mogą kontrolować, współpracuja ze sobą w sprawach dotyczących wspólnych interesów. Istnienie kontroli, która pozwala wszystkim uczestniczącym państwom decydować o rozmiarze i naturze współpracy, oznacza, że narodowa suwerenność jest niezachwiana" ${ }^{18}$. Główną cechą metody międzyrządowej jest to, że decyzje organów organizacji są podejmowane jednomyślnie przez przedstawicieli państw członkowskich.

Metoda międzyrządowa jest przeciwieństwem metody wspólnotowej. W ramach tej drugiej państwa współpracują ze sobą w sposób, który nie pozwala im na zachowanie kompletnej kontroli nad rozwojem organizacji. Oznacza to, że państwa mogą być zobowiązane do akceptacji decyzji organów organizacji, które są przeciwne ich preferencjom i woli, ponieważ nie maja władzy, żeby zablokować podjęcie tych decyzji. Metoda wspólnotowa zmienia stosunki między państwami członkowskimi, które ze współpracy przekształcają się $\mathrm{w}$ integrację. To pociaga za sobą ubytek suwerenności narodowej państw członkowskich ${ }^{19}$.

RTC nie przewiduje stosowania metody wspólnotowej, chociaż dopuszcza pewne odmiany metody międzyrządowej. Procesy decyzyjne w najważniejszych organach CARICOM zostaną zaprezentowane niżej.

\section{Konferencja Szefów Rządów (CHG)}

Najwyższym organem CARICOM jest Konferencja Szefów Rządów (CHG). Jak sama nazwa wskazuje, w skład tego organu wchodzą szefowie rządów państw członkowskich. Zgodnie z postanowieniami art. 12 RTC Konferencja wyznacza polityczne priorytety współpracy dla CARICOM, decyduje o zawieraniu umów międzynarodowych i nawiązaniu stosunków zewnętrznych z państwami i innymi organizacjami międzynarodowymi ${ }^{20}$. CHG jest też najwyższym autorytetem w sprawach finansowych Wspólnoty Karaibskiej i może ustanawiać nowe organy i komitety CARICOM. Na mocy postanowień art. 12(5) RTC Konferencja może rozszerzyć swoje kompetencje bez konieczności zmiany traktatu.

${ }^{18}$ N. Nugent, The Government and Politics of the European Union, wyd. 6, Palgrave Macmillan, Basingstoke 2006, s. 47.

${ }^{19}$ Ibidem.

${ }^{20}$ Art. 12(3) RTC. 
Procedury głosowania dla wszystkich organów CARICOM określa art. 27 RTC. Jednakże art. 28 RTC przewiduje specjalne zasady i procedury dla CHG. Zgodnie z tymi postanowieniami i z zastrzeżeniem ustanowionym w art. 27(2) RTC, każde państwo członkowskie ma na forum Konferencji jeden głos. Artykuł 27(2) RTC przewiduje, że państwo członkowskie może być pozbawione prawa głosu, jeżeli ma dwuletnie zaległości z opłacaniem składki członkowskiej do budżetu Wspólnoty, chyba że dowiedzie, że te zaległości są spowodowane sytuacja poza jego kontrola. Nawet w sytuacji pozbawienia państwa prawa głosu z tego powodu ma ono prawo głosować w sprawach związanych ze Wspólnym Rynkiem i Gospodarką CARICOM, jak również może brać udział w obradach organów i komitetów CARICOM.

CHG może podejmować dwa rodzaje decyzji o charakterze wiążącym: proceduralne i merytoryczne. Jeżeli chodzi o sprawy proceduralne, decyzje CHG sa podejmowane zwykła większością głosów. W sprawach merytorycznych art. 28(1) RTC ustanawia zasadę jednomyślności i wymaga potwierdzającego głosu wszystkich członków CHG w celu podjęcia wiążącej decyzji. W praktyce od tej zasady występują wyjątki. Artykuł 28(2) RTC przewiduje np., że wstrzymanie się od głosowania przez państwo członkowskie nie stanowi przeszkody przy podjęciu decyzji. Z kolei art. 28(3) RTC stwierdza, że wstrzymanie się przez państwo od głosu nie wpływa na ważności decyzji, jeżeli trzy czwarte członków CHG głosowało za jej podjęciem, a żadne nie było przeciwne. Artykuł 28(4) RTC przewiduje natomiast, że państwo członkowskie, które jest strona w sporze rozstrzyganym przez CHG albo na które CHG zamierza nałożyć sankcje, nie ma prawa do głosowania w tych spawach. W kilku bardzo ograniczonych sytuacjach, które mają drugorzędne znaczenie, RTC przewiduje, że w sprawach merytorycznych CHG może podjąć decyzje zwykłą większością głosów ${ }^{21}$.

\section{Rada Wspólnoty (CCM)}

Każde państwo członkowskie desygnuje jednego ministra, zwykle odpowiedzialnego za sprawy wspólnotowe albo innego, który uczestniczy w pracach Rady. CCM sprawuje władzę wykonawcza, zgodnie z założeniami przyjętymi podczas Konferencji Szefów Rządu. CCM jest odpowiedzialna zwłaszcza za rozwój CSME, planowanie strategiczne oraz koordynację współpracy w zakresie integracji gospodarki, współpracy funkcjonalnej oraz stosunków zewnętrznych. CCM jest także organem, który zajmuje się sprawami budżetowymi, gromadzeniem środków potrzebnych do zrealizowania przyjętych programów i kontrolą implementacji decyzji CHG i działalności organów pomocniczych

CCM może uchwalać dyrektywy, decyzje i zalecenia. Jeżeli chodzi o dyrektywy, to RTC nie określa ani reguł proceduralnych ich uchwalania, ani ich mocy prawnej. Artykuł 13(4)(h) RTC sugeruje, że dyrektywy nie mają mocy wiążącej. To samo dotyczy zaleceń. Jeżeli chodzi o decyzje, to art. 29 RTC ustanawia zasady podejmowania merytorycznych decyzji przez CCM. Do ich

${ }^{21} \mathrm{~Np}$. art. 5 RTC pozwala w CHG podejmować decyzje większością głosów w sprawie zmiany statusu państwa członkowskiego z państwa lepiej rozwiniętego (More Developed Country) na państwo mniej rozwinięte (Less Developed Country) i vice versa. 
uchwalenia wymagana jest kwalifikowana większość głosów. Przepis ten definiuje kwalifikowaną większość głosów jako wymagająca pozytywnych głosów trzech czwartych członków CCM. Jednomyślność nie jest więc wymagana jako zasada i sprzeciw członka lub członków CCM nie przeszkadza w podjęciu wiążącej decyzji, jeżeli trzy czwarte członków CCM głosowało za jej podjęciem. Jednakże art. 29(3-5) RTC przewiduje wyjątek od zasady głosowania większością kwalifikowaną. W sytuacji kiedy decyzja dotyczy sprawy o „krytycznej ważności dla dobra narodowego" państwa członkowskiego, wymagana jest albo jednomyślność (wyłączając głos państwa zainteresowanego), albo pozytywne głosy co najmniej trzech czwartych członków CCM, tzn. że żaden członek nie wyraził sprzeciwu i że co najmniej trzy czwarte członków głosowało za podjęciem decyzji. Dodać należy, że ustalenie, czy decyzja dotyczy sprawy o „krytycznej ważności dla dobra narodowego” państwa członkowskiego, jest przedmiotem głosowania, a nie pozostawiona zainteresowanemu państwu do jego własnej oceny ${ }^{22}$.

\section{Rady ministrów: COFAP, COTED, COFCOR i COHSOD}

W hierarchii organów CARICOM poniżej CCM znajdują się cztery rady ministrów: Rada do spraw Finansów i Planowania (COFAP), Rada do spraw Handlu i Rozwoju Gospodarczego (COTED), Rada do spraw Zagranicznych i Wspólnotowych (COFCOR) i Rada do spraw Rozwoju Społecznego (COHSOD). W skład każdej z nich wchodzi jeden minister desygnowany przez państwo członkowskie. Zasady podejmowania wiążących merytorycznych decyzji przez powyższe rady są takie same jak te, które dotyczą CCM.

\section{Konkluzje}

Przyjęcie metody międzyrządowej w procesie podejmowania decyzji przez organy CARICOM i kompletne odrzucenie metody wspólnotowej to główne hamulce rozwoju integracji w ramach CARICOM. Jednomyślność, albo też uwarunkowanie możliwości podjęcia wiążących decyzji brakiem weta, oznacza, że tylko w bardzo ograniczonym zakresie interesy wszystkich państw członkowskich będą zbieżne. Najlepszym przykładem wskazującym na to, że metoda międzyrządowa paraliżuje integrację, była sytuacja w EWG przed wejściem w życie Jednolitego Aktu Europejskiego (JAE). W tym okresie metoda międzyrządowa była jedyną stosowaną w procesie podejmowaniu decyzji przez instytucje Wspólnoty. Jej konsekwencją była stagnacja EWG. JEA zmienił zasadę głosowania w Radzie Ministrów z jednomyślności na większość kwalifikowana, co pozwoliło Wspólnocie na zrealizowanie ambitnego projektu stworzenia rynku wewnętrznego.

W konkluzji można powiedzieć, że przywiązywanie nadmiernej wagi do suwerenności przez państwa członkowskie CARICOM nie przynosi im korzyści na dłuższą metę. Absolutna dominacja metody międzyrządowej może prowadzić w określonej perspektywie czasowej do „demontażu” Wspólnoty.

\footnotetext{
22 Art. 29(4) RTC.
} 


\section{BRAK SANKCJI \\ W STOSUNKU DO PAŃSTWA CZLONKOWSKIEGO, KTÓRE NIE STOSUJE SIE DO ORZECZENIA CCJ STWIERDZAJĄCEGO NARUSZENIA PRAWA WSPÓLNOTOWEGO}

\section{Wprowadzenie}

Dla zaprezentowania tego zagadnienia należy porównać sytuację Europejskiego Trybunału Sprawiedliwości z okresu, gdy nie miał on wyraźnej kompetencji traktatowej do nakładania sankcji na państwa członkowskie, które nie stosowały się do jego orzeczeń stwierdzających naruszenie prawa wspólnotowego, z sytuacją Karaibskiego Trybunału Sprawiedliwości, któremu RTC również nie daje wyraźnej kompetencji w tej sferze. To porównanie zostanie przeprowadzone w oparciu o regulacje traktatowe w taki sposób, aby wskazać na istnienie potencjalnych mechanizmów, które mogłyby być użyte przez oba Trybunały w celu zmuszenia państw członkowskich do przestrzeganie prawa wspólnotowego.

\section{Pozycja Europejskiego Trybunału Sprawiedliwości}

Historia EWG pokazuje, że brak sankcji za niewykonanie orzeczeń Europejskiego Trybunału Sprawiedliwości przez państwa członkowskie pociaga za sobą poważne konsekwencje. Nie tylko bezkarnie naruszały one prawo wspólnotowe, ale także odmowę wykonania orzeczeń wykorzystywały jako argument w negocjowaniu spornych kwestii z instytucjami Wspólnoty. Jednym z najlepszych przykładów w tej mierze jest sprawa 232/78 - Komisja Europejska przeciwko Francji ${ }^{23}$, w której Europejski Trybunał Sprawiedliwości stwierdził, że Francja naruszyła traktat przez narzucenie zakazu importu do Francji brytyjskiej jagnięciny i baraniny. Francja odmówiła wykonania orzeczenia i kontynuowała ten zakaz. Komisja Europejska rozpoczęła nowe postępowanie przeciwko Francji w celu zmuszenia jej do wykonania orzeczenia i jednocześnie złożyła wniosek do Trybunału o nałożenie środków tymczasowych na Francję ${ }^{24}$. Trybunał odmówił, stwierdzajac, że ich nałożenie byłoby tylko powtórzeniem wcześniejszego orzeczenia. Trudno się dziwić bezsilności Trybunału, który zdawał sobie sprawę z tego, że wydanie orzeczenia nakładającego środki tymczasowe podważyłoby powagę sądu, biorąc pod uwagę wysokie prawdopodobieństwo zignorowania go przez Francję, co w konsekwencji prowadziłoby do wydania następnego orzeczenia. Odmowa wydania orzeczenia dotyczącego środków tymczasowych postawiła Francję w bardzo dobrej pozycji przetargowej w stosunku Komisji, od której Francja domagała się poparcia dla interesów francuskich hodowców owiec. Kiedy to uzyskała i po otrzymaniu

\footnotetext{
23 Case 232/78 Commission v France [1979], ECR-2729.

${ }^{24}$ Case 24/80R Commission v France [1980], ECR-1319.
} 
koncesji od Wielkiej Brytanii, w zamian za które ta ostatnia otrzymała rabat na składki do budżetu Wspólnoty, Francja zniosła zakaz ${ }^{25}$.

Bezkarne naruszanie prawa wspólnotowego skończyło się wraz z wprowadzeniem przez Traktat z Maastricht możliwości nałożenia sankcji na państwo członkowskie, które nie stosuje się do orzeczenia Europejskiego Trybunału Sprawiedliwości ${ }^{26}$. Te sankcje zostały jeszcze zaostrzone przez traktat lizboń$\mathrm{ski}^{27}$. Na mocy postanowień art. 260(2) TfUE sankcje takie polegają na nałożeniu płatności ryczałtowej albo kary dziennej, albo obu. Płatność ryczałtowa musi być realizowana przez państwo członkowskie bezzwłocznie, natomiast kary dzienne sa płacone do czasu całkowitego zastosowania się do pierwszego i drugiego wyroku Trybunału. Sankcje nałożone na państwo członkowskie sa bardzo skutecznym środkiem do zapewnienie poszanowania prawa UE. Według sprawozdania Komisji Europejskiej, dotyczącego stosowania prawa UE przez państwa członkowskie w 2012 r. ${ }^{28}$, pod koniec tego roku Komisja prowadziła 128 postępowań na mocy art. 260(2) TfUE, z których 11 zostało wniesionych do Trybunału. W 2012 r. Trybunał wydał trzy wyroki: dwa przeciwko Irlandii i jeden przeciwko Hiszpanii stwierdzające niezastosowanie się przez te państwa do orzeczeń Trybunału ${ }^{29}$.

\section{Pozycja Karaibskiego Trybunału Sprawiedliwości}

RTC nie daje CCJ wyraźnej kompetencji do nakładania sankcji na państwo członkowskie, które odmawia wykonania orzeczenia tego Trybunału. Podobnie jak ETS w sprawie 24/80R - Komisja Europejska przeciwko Francji, CCJ w sprawie dotyczacej skargi TCL i TGI przeciwko Gujanie stanął przed koniecznością zadecydowania o tym, czy ma kompetencje do nałożenia sankcji na państwo członkowskie, które odmawia zastosowania się do jego orzeczenia. W tej sprawie CCJ rozważał, czy może orzec, że Gujana albo adwokat generalny (AG) Gujany lub też Gujana i jej AG obrazili sąd przez niezastosowanie się do jego orzeczenia.

Należy podkreślić, że prawo dotyczące obrazy sądu, które rozwijało się przez stulecia w systemie common law, jak to stwierdził CCJ w sprawie Trinidad Cement Limited (TCL), TCL Guyana Incorporated przeciwko Gujanie ${ }^{30}$, nie ma odpowiednika w systemie kontynentalnym ${ }^{31}$.

W polskim prawie obraza sądu jest regulowana przez art. 49 ustawy o ustroju sąów powszechnych. Zgodnie z tymi postanowieniami i ich interpretacją przez Sąd Najwyższy, na osobę, która obraziła sąd może być nałożona

\footnotetext{
${ }^{25} \mathrm{Na}$ temat wolnego handlu baraniną i jagnięciną w EWG zob. np. F. Snyder, New Directions in Community Law, Weidefield and Nicolson, London 1990.

${ }^{26}$ P. Wenneras, New Dawn for Commission Enforcement under Articles 226 and 227 EC. General and Persistent Infringements, Lump Sums and Penalty Payments, „Common Market Law Review" 43, 2006, s. 31.

${ }^{27}$ L. Prete, B. Smulders, The Coming of Age of Infringement Proceedings, „Common Market Law Review" 47, 2010, s. 9.

${ }^{28}$ COM (2013), 726 final.

${ }^{29}$ Ibidem, s. 11.

${ }^{30}$ [2010] CCJ 1 (OJ), para. 30.

${ }^{31}$ M. Chestman, Contempt: In Common Law, but not the Civil Law, „International Comparative Law Quarterly" 46, 1997, s. 521.
} 
kara porzadkowa w postaci grzywny do 10 tysięcy złotych albo kara pozbawienia wolności do dwóch tygodni. Jednakże taka kara może być nałożona tylko wobec sprawców czynów naruszających powagę sądu w czasie i w miejscu wykonywania czynności sądowej, a więc w praktyce w czasie rozprawy lub posiedzenia sądu ${ }^{32}$.

W państwach z systemem common law obraza sądu jest często regulowana przez ustawy i common law $w^{33}$. Obraza sądu obejmuje czyny dokonane w czasie rozprawy lub poza rozprawa, które podważają autorytet wymiaru sprawiedliwości i zaufanie obywateli do sądów i sędziów. Prawne konsekwencje obrazy sądu sa takie, że sędzia może nałożyć na sprawcę albo karę grzywny, albo karę pozbawienia wolności. Dodatkowo w stosunku do cywilnej obrazy sądu (zob. poniżej) sędzia może nakazać zajęcie mienia sprawcy albo - w przypadku podmiotów gospodarczych, takich jak np. spółka - członków ich zarządów ${ }^{34}$. Według common law nie ma określonych granic kary pozbawienia wolności, jaka może być wymierzona przez sąd. Skazany może więc pozostać w więzieniu dopóty, dopóki nie zastosuje się do decyzji wydanej przez sąd. Common law wyróżnia dwie formy obrazy sądu: karną i cywilną. Karna dotyczy zachowania, które zagraża nienaruszalności systemu prawnego danego państwa (np. ubliżanie sędziemu w czasie rozprawy, odmowa składania zeznań przez świadka, rejestrowanie rozprawy bez zgody sądu lub odmowa wyjawienia źródła informacji wykorzystanej np. w publikacji prasowej, jeżeli zdaniem sądu jest to niezbędne z punktu widzenia interesu wymiaru sprawiedliwości, bezpieczeństwa publicznego lub uniemożliwienia popełnienia przestępstwa. Może dotyczyć to również zachowań mających miejsce poza rozprawa, takich jak np. opublikowanie materiałów stwarzających poważne ryzyko, że prowadzenie sprawy będzie poważnie utrudnione, albo przekupienie świadka ${ }^{35}$ ). Cywilna obraza sądu dotyczy sytuacji, w których dana osoba odmawia wykonania decyzji albo orzeczenia sądu w sprawie cywilnej lub działa niezgodnie $\mathrm{z}$ formalną obietnicą daną sądowi, na podstawie której sąd podją szczególny tok działania lub takiego zaniechał ${ }^{36}$. Zarówno w przypadku karnej, jak i cywilnej obrazy sądu sędzia może zadecydować na rozprawie o natychmiastowym wykonaniu kary, $\mathrm{w}$ tym kary pozbawienia wolności. Zgodnie z common law w wypadku karnej obrazy sądu nie ma możliwości odwołania się od decyzji sądu.

W sprawie TCL i TGI przeciwko Gujanie CCJ nie zasądził odszkodowania na rzecz powodów ${ }^{37}$, ale nakazał Gujanie, w ciagu 28 dni od dnia wydania

${ }^{32}$ Sąd Najwyższy (I KZP 8/11). Sąd Najwyższy stwierdził, że kara porządkowa nie stosuje się do czynów obrażających sąd, które mają miejsce poza rozprawą czy posiedzeniem sądu, i tym samym wykluczył możliwość nałożenia kary porządkowej w sytuacji, np. gdy ubliżenie sądowi przybrało formę pisemna. Na ten temat zobacz: http://prawo.rp.pl/artykul/740189.html (dostęp: 28.05.2014).

${ }^{33}$ Zob. np. prawo brytyjskie na temat obrazy sądu i jego proponowana reforma przez UK Law Reform Commission (http://lawcommission.justice.gov.uk/areas/contempt.htm [dostęp: 10.05.2014]).

${ }^{34}$ Lord McKay of Clashfern (red.), Halsbury's Laws of Enhland, LexisNexis, Butterworths 2014, wyd. 5, t. 22, Contempt of Court, s. 55, par. 65.

${ }^{35}$ Ibidem, s. 5-54, par. 5-64.

${ }^{36}$ Ibidem, par. 65-200.

${ }^{37}$ Trinidad Cement Limited, TCL Guyana Incorporated $v$ The State of The Co-operative Republic of Guyana [2009], CCJ 6 (OJ). 
orzeczenia (tj. od 20 sierpnia 2009 r.), przywrócenie CET na cement importowany spoza terytorium CARICOM ${ }^{38}$. Dzień przed upływem terminu, a więc 16 września 2009 r. Gujana złożyła do CCJ formalny wniosek o jego przedłużenie $^{39}$. W tej sytuacji TCL zażądała, aby CCJ odmówił wysłuchania Gujany albo oddalił jej wniosek, wskazując jako podstawę swojego żądania fakt, że Gujana obraziła sąd przez odmowę przywrócenia CET w wyznaczonym wyrokiem terminie. Alternatywnie TCL wniosła o zawieszenie postępowania w tej sprawie aż do momentu wydania orzeczenia w innej sprawie z powództwa TCL z 15 października 2009 r., w której ta ostatnia wniosła o stwierdzenie przez CCJ, że AG Gujany obraził sąd. CCJ stwierdził, że odmowa wysłuchania strony, nawet takiej, która obraziła sąd, albo oddalenie sprawy bez wysłuchania strony byłyby środkiem o „drakońskim” charakterze uzasadnionym tylko w ostateczności ${ }^{40}$. CCJ zdecydował się wysłuchać argumentów Gujany z trzech powodów: po pierwsze - dlatego że sąd ma zawsze dyskrecję, jeżeli chodzi o wysłuchanie strony, po drugie - dlatego że Gujana zwróciła się do CCJ o przedłużenie terminu przywrócenia CET przed jego upływem i - po trzecie - wreszcie dlatego że chociaż Trybunał tego wyraźnie nie stwierdził, sytuacja nie wymagała zastosowania takich drakońskich środków. Ostatecznie CCJ oddalił żądanie Gujany o przedłużenie terminu przywrócenia CET. W konsekwencji Gujana tylko częściowo przywróciła CET (15 października 2009 r.).

Jeżeli natomiast chodzi o skargę TCL z 15 października 2009 r., to powód wnosił w niej o stwierdzenie, że:

1) AG Gujany powinien stanąc przed CCJ w sprawie dotyczącej obrazy CCJ, wynikajacej z odmowy wykonania przez Gujanę orzeczenia nakazującego przywrócenia CET w terminie wyznaczonym przez CCJ;

2) przez odmowę wykonania orzeczenia przez Gujanę jej AG obraził sąd;

3) przez odmowę wykonania orzeczenia Gujana naruszyła art. 215 RTC, który zobowiąuje państwa członkowskie, organy i komitety CARICOM, jak również osoby, przeciwko którym CCJ wydał orzeczenie, do szybkiego zastosowania się do takiego orzeczenia ${ }^{41}$.

Dodatkowo w czasie rozprawy w fazie procedury ustnej TCL poprosił CCJ o wydanie deklaracji stwierdzającej, że Gujana obraziła sąd w ten sposób, że nie zastosowała się do orzeczenia z 20 sierpnia 2009 r.

Trybunał zajął następujace stanowisko w tych trzech kwestiach:

1. Z powodów proceduralnych oddalił wniosek TCL dotyczący stwierdzenia, że Gujana obraziła sąd. CCJ stwierdził, że nawet gdyby miał jurysdykcję w stwierdzenia cywilnej obrazy sądu przez Gujanę (co do której istnienia CCJ miał wattpliwości), procedura wymaga, aby pozwany został powiadomiony o zarzucie obrazy sądu w czasie pozwalajacym mu na przygotowanie obrony ${ }^{42}$. Ten wymóg nie został spełniony przez powoda.

${ }_{38}$ Trinidad Cement Limited, TCL Guyana Incorporated $v$ The State of The Co-operative Republic of Guyana [2009], CCJ 5 (OJ).

39 Trinidad Cement Limited, TCL Guyana Incorporated $v$ The State of The Co-operative Republic of Guyana [2009], CCJ 6 (OJ).

40 Ibidem, par. 6.

41 Trinidad Cement Limited, TCL Guyana Incorporated $v$ The State of The Co-operative Republic of Guyana [2010], CCJ 1 (OJ).

${ }^{42}$ Ibidem, par. 13. 
2. Trybunał odmówił nie tylko wydania orzeczenia dotyczącego zmuszenia AG do stawienia się w sprawie obrazy sądu przed CCJ, ale też orzeczenia stwierdzającego, że AG obraził sąd. CCJ stwierdził, że nawet gdyby miał jurysdykcję pozwalająca na wydanie takich orzeczeń, okoliczności sprawy i zasady common law odzwierciedlone w prawie wewnętrznym państw członkowskich uniemożliwiały ich wydanie. CCJ uzasadnił swoje stanowisko w ten sposób, że orzeczenie zobowiązujące AG do stawienia się przed Trybunałem byłoby możliwe tylko wtedy, gdyby istniała podstawa prawna do jego wydania. Okoliczności sprawy wskazywały na to, że nie było żadnych dowodów pozwalających na stwierdzenie, że AG był osobiście odpowiedzialny za niewykonanie przez Gujanę orzeczenia z 20 sierpnia 2009 r. albo pomimo że nie był on strona w sprawie pomiędzy TCL i Gujana, był odpowiedzialny za nieprzywrócenie przez Gujanę CET na cement.

3. Trybunał stwierdził, że Gujana naruszyła art. 215 RTC.

Moim zdaniem najciekawsza część orzeczenia dotyczyła uwag CCJ na temat jego kompetencji do wydania orzeczenia stwierdzajacego istnienie obrazy sądu. CCJ stwierdził w związku z tym, że w celu zmuszenia państwa członkowskiego do wykonania orzeczenia Trybunału możliwe jest tylko orzeczenie dotyczące cywilnej obrazy sądu. Następnie CCJ przeanalizował prawo wspólnotowe i prawo międzynarodowe w celu stwierdzenia, czy może wydać takie orzeczenie. Jeżeli chodzi o prawo wspólnotowe, CCJ stwierdził, że nie przewiduje ono w sposób wyraźny istnienia po stronie Trybunału takiej kompetencji. Jednakże stwierdził on, że taka kompetencja może wynikać pośrednio, w szczególności z postanowień art. XXVI(b) umowy ustanawiającej CCJ ${ }^{43}$. $\mathrm{Na}$ podstawie tych postanowień CCJ ma kompetencje do wydawania takich samych orzeczeń i decyzji, jak najwyższe organy sądowe państw członkowskich. W tym miejscu CCJ dodał, że biorąc pod uwagę fakt, że najwyższe organy sądowe państw członkowskich, których systemy prawne oparte są na prawie kontynentalnym, nie mają takiej kompetencji, w związku z czym wątpliwa jest teza, że taka kompetencja CCJ może wynikać pośrednio z prawa wspólnotowego.

CCJ dokonał również wykładni prawa międzynarodowego w zakresie dotyczacym obrazy sądu. Trybunał stwierdził w związku z tym, że jeżeli chodzi o karną obrazę sądu, jej istnienie jest uznawane przez prawo międzynarodowe ${ }^{44}$. Natomiast możliwość powołania się na prawo międzynarodowe w zakresie cywilnej obrazy sądu nie jest do końca jasna ${ }^{45}$. W tej sytuacji CCJ zdecydował nie wypowiadać się w sprawie dotyczacej jego kompetencji opartej na prawie międzynarodowym, a dotyczącej możliwości stwierdzenia, że państwo członkowskie obraziło sąd przez niezastosowanie się do jego orzeczenia.

43 Tekst tego porozumienia można znaleźć na: http://www.caricom.org/jsp/secretariat/legal_ instruments/agreement_ccj.pdf (dostęp: 12.05.2014).

${ }_{44}$ Zobacz w szczególności: sprawa Prosecutor v. Tadić, Case No. IT-94-1-A-R77, par. 13. Wyrok dotyczacy Allegations of Contempt against Prior Counsel, Milan Vujin, przed the Appeals Chamber of the International Tribunal for the former Yugoslavia i sprawa Beqa Beqaj No. IT-0366-T-R77 przed the Trial Chamber.

45 Trinidad Cement Limited, TCL Guyana Incorporated $v$ The State of The Co-operative Republic of Guyana [2010] CCJ 1 (OJ), par. 38. 
Stanowisko CCJ dotyczące możliwości powołania się na cywilną obrazę sądu jako środek zmuszający państwo członkowskie do wykonania orzeczenia Trybunału jest niezbyt czytelne. Jest to poniekąd zrozumiałe, biorac pod uwagę fakt, że w stosunku do suwerennego państwa nie jest możliwe przeprowadzenie klasycznej egzekucji orzeczenia. Ostatecznie jednak CCJ stwierdził, że konsekwencje wynikające ze stwierdzenia, że państwo członkowskie naruszyło art. 215 RTC, sa podobne do tych, które wynikają ze stwierdzenia, że państwo członkowskie obraziło sąd.

\section{Konkluzje}

Podsumowując tę część rozważań, można powiedzieć, że ani Europejski Trybunał Sprawiedliwości, w czasie gdy nie miał kompetencji do nakładania sankcji na państwa członkowskie, ani Karaibski Trybunał Sprawiedliwości nie uważaja, że nałożenie sankcji na państwo członkowskie jest dobrym środkiem prowadzacym do wymuszenia zastosowania się do ich orzeczeń. Takie stanowisko jest zrozumiałe nie tylko ze względu na niemożliwość przeprowadzenia egzekucji takich orzeczeń, lecz także ze względu na to, że jedynie zgoda państw członkowskich na zastosowanie sankcji zapewnia ich skuteczność. W rezultacie tylko wprowadzenie poprawki do RTC, pozwalającej CCJ na nakładanie sankcji na państwa członkowskie, które nie stosują się do jego orzeczeń, jest realnym sposobem na zapewnienie przestrzegania przez państwa prawa wspólnotowego. Niestety, państwa członkowskie CARICOM nie sa jeszcze gotowe na przyjęcie takiego rozwiązania.

\section{KONKLUZJE KOŃCOWE}

Po to, aby CSME mogła skutecznie funkcjonować i realizować ambitne zadania zdefiniowane w art. 6 RTC, niezbędne jest przewartościowanie stanowiska państw członkowskich w ten sposób, żeby zrozumiały, że ich wizja suwerenności, oparta na dziewiętnastowiecznych teoriach i realiach, nie odpowiada już wymogom XXI w.

W dzisiejszym świecie, dzięki rewolucji informatycznej, rozwojowi naukowo-technicznemu, liberalizacji międzynarodowych stosunków gospodarczych, internacjonalizacji kapitału i wzrostowi znaczenia międzynarodowych organizacji i korporacji, nie ma chyba państwa, które mogłoby powiedzieć, że jest stuprocentowo suwerenne zgodnie z definicją prof. Zbigniewa Witkowskiego. Według tej definicji suwerenność jest to „pojęcie oznaczające stan państwa zdolnego do nieskrępowanego niczym i przez nikogo samodzielnego decydowania we wszystkich sprawach go dotyczacych - w sferze politycznej, militarnej, ekonomicznej”46. W szczególności małe i słabo rozwinięte państwa regionu karaibskiego, których głównym źródłem dochodu narodowego są: turystka,

${ }^{46}$ Z. Witkowski (red.), Prawo konstytucyjne, TNOiK, Toruń 2002, s. 70. 
eksport cukru i bananów, powinny zrozumieć, że w ich narodowym interesie jest harmonijny rozwój całego regionu, który może być osiagnięty tylko przez zaakceptowanie konsekwencji wynikających z globalizacji. To z kolei wymaga nowej percepcji pojęcia suwerenności, które z jednej strony powinno pasować do współczesnego globalizmu, ale z drugiej powinno zapewnić, że integracja $\mathrm{w}$ ramach CSME będzie miała tzw. zawory bezpieczeństwa, np. w postaci zasady subsydiarności, wyraźnego podziału kompetencji pomiędzy państwa członkowskie i CARICOM oraz gwarancji, że CARICOM pozostanie organizacja, która szanuje prawo, rozwija demokrację, chroni podstawowe prawa człowieka i dba o ludzki wymiar polityki.

Słabości RTC są liczne. Traktat ten, oprócz zaakceptowania dualizmu, który stanowi przeszkodę ustanowienia zasady bezpośredniego stosowania i bezpośredniej skuteczności prawa wspólnotowego, przewiduje stosowanie zasady jednomyślności w podejmowaniu decyzji przez organy CSME, co bez wątpienia hamuje rozwój CSME. Poza tym pozwala on na bezkarność państw członkowskich, których nie można zmusić do wykonania orzeczeń CCJ stwierdzających naruszenie przez nie prawa wspólnotowego. Można wskazać na jeszcze inne ułomności RTC. Zasada prymatu prawa wspólnotowego jest nieznana w prawie CARICOM, jej system instytucjonalny nie przewiduje istnienia organu o kompetencjach podobnych do tych, jakie realizuje Komisja Europejska (nie ma zatem tzw. strażnika traktatów), nie ma też żadnego organu ani mechanizmu, który pozwalałby obywatelom państw członkowskich na bezpośrednie lub pośrednie uczestniczenie w procesie podejmowaniu decyzji w ramach CSME. Dodać do tego jeszcze należy, że zasada przejrzystości nie jest $\mathrm{w}$ praktyce stosowana, poszanowanie praw człowieka nie jest priorytetem w stosowaniu prawa wspólnotowego, a swoboda przepływu pracowników jest bardzo ograniczona. Mimo to nie powinniśmy oceniać CARICOM nazbyt surowo. Jest to stosunkowo młoda organizacja, która, tak jak Unia Europejska, potrzebuje czasu i doświadczenia, żeby osiagnąć dojrzałość pozwalająca jej na rozwinięcie skrzydeł, na mentalne wyzwolenie się z kolonialnej przeszłości i uświadomienie sobie, że „united we stand, divided we fall”.

prof. dr Alina Kaczorowska-Ireland

Uniwersytet Indii Zachodnich, Cave Hill Campus, Barbados

alina.kaczorowska@cavehill.uwi.edu

\author{
PROSPECTS OF FURTHER DEVELOPMENT OF THE CARIBBEAN REGION \\ INTEGRATION UNDER THE REVISED TREATY OF CHAGUARAMAS
}

Summary

The Revised Treaty of Chaguaramas (RTC), which came into force in January 2006, transformed the Common Market, established in 1973 by the Caribbean Community (CARICOM) pursuant to the Treaty of Chaguaramas, into the CARICOM Single Market and Economy (CSME). This article analyses the three main obstacles that impede the progress in the deepening of regional integration within the framework of the RTC. They are: attachment of the Member States to dualism, the decision-making process in the CSME based on the inter-governmental method, 
and the lack of sanctions that could be put on a Member State for refusal to comply with a judicial decision rendered by the Caribbean Court of Justice (CCJ) upon finding a Member State in breach of Community law. The CCJ has compulsory and exclusive jurisdiction to interpret and apply the RTC, and, like the European Court of Justice with regard to European Union (EU) law, is the main engine of integration within the RTC. This article examines possible options, in light of the EU's experience and judgments delivered by the CCJ, which have allowed overcoming the difficulties resulting from the existence of the above obstacles, with a view to advancing integration in the Caribbean region. 
Copyright of Journal of Law, Economics and Sociology is the property of Faculty of Law and Administration of Adam Mickiewicz University in Poznan and its content may not be copied or emailed to multiple sites or posted to a listserv without the copyright holder's express written permission. However, users may print, download, or email articles for individual use.

Właścicielem praw autorskich do „Ruchu Prawniczego, Ekonomicznego i Socjologicznego” jest Wydział Prawa i Administracji Uniwersytetu im. Adama Mickiewicza w Poznaniu. Zawartość czasopisma nie może być kopiowana, przesyłana do innych stron internetowych bądź zamieszczana na blogach bez pisemnej zgody wydawcy. Niemniej artykuły można drukować, kopiować lub przesyłać w formie elektronicznej na własny użytek. 